Joanna M. Karolczak

\title{
Wygaszenie mandatu radnego, który nie zamieszkuje w gminie, z której uzyskał mandat ${ }^{1}$
}

\begin{abstract}
Expiration of the mandate of a councillor, who does reside in a commune, in which the mandate was obtained: Passive and active electoral right in elections to bodies of local government units is related to the fact of a permanent residence in the area of the given local government unit, and not to the fact of a permanent registration. If the councillor fails to fulfil the condition of factual permanent residence during the term of office, the right to be elected is lost, what results in the expiration of the mandate. The expiration is declared by the respective communal council in a form of a resolution, after conducting explanatory proceedings and providing the councillor with an opportunity to deliver explanations.
\end{abstract}

Keywords: mandate, councillor, local government

Słowa kluczowe: mandat, radny, samorząd terytorialny

Radca prawny, ekspert ds. legislacji BAS • joanna.karolczak@sejm.gov.pl • https://orcid.org/0000-0002-5421-4683

\section{Przedmiot opinii}

W opinii przedstawione zostaną odpowiedzi na pytania: czy radnemu do uznania prawa do kandydowania i pełnienia mandatu w danej gminie wystarczy zameldowanie w tej gminie, czy też musi on mieszkać w niej faktycznie? Jeśli radny nie zamieszkuje w danej gminie, a jest tylko w niej zameldowany, to jakie kroki należy podjąć, żeby skutecznie wygasić mandat? Kto może to zrobić, w jakich terminach, jaka jest procedura wygaszenia? Czy z taką inicjatywą mogą wyjść mieszkańcy.

Opinię sporządzono na podstawie następujących ustaw:

- ustawa z 5 stycznia 2011 r. - Kodeks wyborczy, t.j. Dz.U. 2018, poz. 754, ze zm.,

1 Opinia prawna dotyczaca wygaszenia mandatu radnego, który nie zamieszkuje w gminie, z której uzyskał mandat sporządzona 1 lutego 2019 r. na zlecenie posła Klubu Parlamentarnego Platforma Obywatelska - Koalicja Obywatelska; BAS-WAP 96/19. 
- ustawa z 8 marca 1990 r. o samorządzie gminnym, t.j. Dz.U. 2018, poz. 994, ze zm.; dalej: u.s.gm.,

- ustawa z 24 września 2010 r. o ewidencji ludności, t.j. Dz.U. 2018, poz. 1382, ze zm.,

- ustawa z 23 kwietnia 1964 r. - Kodeks cywilny, t.j. Dz.U. 2018, poz. 1025, ze zm.

\section{Uzasadnienie}

\section{Miejsce zamieszkanie radnego}

Zgodnie $\mathrm{z}$ art. $11 \S 1$ pkt 5 Kodeksu wyborczego prawo wybieralności (bierne prawo wyborcze) w wyborach do organów stanowiących jednostek samorządu terytorialnego ma osoba posiadająca prawo wybierania tych organów.

Zgodnie $\mathrm{z}$ art. $10 \$ 1$ pkt 3 tego Kodeksu prawo wybierania (czynne prawo wyborcze) w wyborach do organów stanowiących jednostek samorządu terytorialnego:

a) do rady gminy ma obywatel polski oraz obywatel Unii Europejskiej niebędący obywatelem polskim, który najpóźniej w dniu głosowania kończy 18 lat oraz stale zamieszkuje na obszarze tej gminy,

b) do rady powiatu i sejmiku województwa ma obywatel polski, który najpóźniej w dniu głosowania kończy 18 lat oraz stale zamieszkuje na obszarze, odpowiednio, tego powiatu i województwa.

Przepisy te nie wiążą więc biernego i czynnego prawa wyborczego $\mathrm{z}$ faktem zameldowania w danej gminie (powiecie, województwie), a z faktem „stałego zamieszkiwania".

W art. 5 pkt 9 Kodeksu zdefiniowano „stałe zamieszkiwanie” jako zamieszkanie w określonej miejscowości pod oznaczonym adresem z zamiarem stałego pobytu.

W literaturze wskazuje się, że o miejscu zamieszkania rozstrzyga trwała zmiana sytuacji faktycznej, nie zaś tylko przejściowe, choćby długotrwałe, zaniechanie przebywania $\mathrm{w}$ dotychczasowym miejscu zamieszkania czy przejściowa zmiana zamiaru stałego pobytu w tej miejscowości. Ustawodawca nie wiąże dla potrzeb określenia praw wyborczych oceny stałego zamieszkania z zameldowaniem. Trzeba podkreślić, że przepisy prawne stanowią, iż równocześnie można mieć tylko jedno miejsce pobytu stałego (zamieszkania). Wynika to $\mathrm{z}$ art. 27 ust. 2 ustawy o ewidencji ludności ${ }^{2}$, a także z art. 28 Kodeksu cywilnego ${ }^{3}$. Jakkolwiek

2 Zgodnie z art. 27 ust. 2 tej ustawy równocześnie można mieć jedno miejsce pobytu stałego i jedno miejsce pobytu czasowego.

3 Art. 28 Kodeksu cywilnego stanowi, że można mieć tylko jedno miejsce zamieszkania. 
nie ma podstaw prawnych do oceny - na użytek prawa wyborczego - stałego zamieszkania wyłącznie na podstawie stałego zameldowania, to przy tej ocenie nie można w ogóle odrzucić faktu stałego zameldowania. Jeżeli zatem wyborca zameldowany na stałe w jednym miejscu powołuje się, w sprawach dotyczących wyborów, na zamiar stałego pobytu w miejscu niebędącym miejscem jego stałego zameldowania i domaga się uznania tego miejsca za miejsce jego stałego zamieszkania w rozumieniu art. 5 pkt 9 Kodeksu wyborczego, to pojawia się wówczas wymagająca wyjaśnienia sprzeczność wynikająca z deklarowania zamiaru stałego pobytu jednocześnie w dwóch różnych miejscach ${ }^{4}$.

Warto powołać się na orzecznictwo dotyczące kwestii związanej z ustalaniem „miejsca zamieszkania” dla potrzeb określania praw wyborczych.

Zdaniem Naczelnego Sądu Administracyjnego (NSA), wyrażonym w wyroku z 11 października 2017 r. ${ }^{5}$ o miejscu zamieszkania dla określenia praw wyborczych decydują dwie przesłanki: przebywanie w znaczeniu fizycznym w określonej miejscowości pod oznaczonym adresem oraz zamiar stałego pobytu w tym miejscu. Na stałość pobytu w danej miejscowości wskazuje skupienie w niej życiowej aktywności związanej nie tylko z pracą, ale również z rodziną. Natomiast rozpatrując zamiar przebywania w oznaczonej miejscowości, należy mieć na uwadze nie tylko wewnętrzne przekonanie danej osoby czy jej zapewnienia, ale również to, aby wystąpiły konkretne i sprawdzalne zachowania będące wyrazem deklarowanego zamiaru. Przy ustalaniu miejsca zamieszkania istotną rolę ma czynnik życia rodzinnego, zaś fakt przebywania w innej miejscowości w związku z wykonywaną pracą zawodową bądź inną działalnością nie może mieć decydującego znaczenia, jeżeli nie idzie za tym koncentracja życia rodzinnego.

W wyroku z 4 lipca 2017 r. ${ }^{6}$ NSA uznał, że decydujące dla ustalenia stałego miejsca zamieszkania kandydata w wyborach samorządowych jest jego centrum interesów życiowych (przede wszystkim rodzinnych i majątkowych), nie zaś miejsce zameldowania na pobyt stały czy też miejsce wpisania do rejestru wyborców.

W wyroku z 19 maja 2016 r. ${ }^{7}$ NSA wskazał istotne przesłanki dotyczące analizowanych kwestii.

- Instytucja zameldowania ma charakter wyłącznie ewidencyjno-porządkowy i nie można utożsamiać miejsca zamieszkania z miejscem zameldowania na pobyt stały, z czynnością zameldowania nie wiąże się bowiem nabycie jakichkolwiek praw i obowiązków.

- Nie ma także znaczenia rozstrzygającego, w kontekście oceny posiadania prawa wyborczego, wpis do rejestru wyborców ani też miejsce opłacania podat-

\footnotetext{
4 A. Kisielewicz, J. Zbieranek, Komentarz do art. 5 [w:] K. Czaplicki, B. Dauter, S. Jaworski i in., Kodeks wyborczy. Komentarz, Wolters Kluwer, 2018.

Sygn. akt II OSK 2082/17, LEX nr 2408834.

Sygn. akt II OSK 862/17, LEX nr 2320812.

7 Sygn. akt II OSK 689/16, LEX nr 2083586.
} 
ków. W postępowaniu w sprawie wygaśnięcia mandatu radnego można bowiem kwestię miejsca zamieszkania oceniać także za pomocą innych dowodów.

- O zamieszkiwaniu w jakiejś miejscowości można mówić wówczas, gdy okoliczności sprawy pozwolą przeciętnemu obserwatorowi na sformułowanie wniosku, że określona miejscowość jest aktualnie głównym miejscem, skupiającym działalność osoby fizycznej, w którym jest jej centrum życiowe.

- Ustalenie miejsca zamieszkania na potrzeby oceny posiadania (lub nie) prawa wybieralności w dniu wyborów przez radnego nie może opierać się na zaszłościach ani na zamiarach, których zrealizowanie nastąpić może w niedającym się określić czasie.

Zdaniem Wojewódzkiego Sądu Administracyjnego w Lublinie, wyrażonym w wyroku z 19 stycznia 2017 r. ${ }^{8}$, rozpatrując przesłankę decydującą o stałym miejscu zamieszkania, tj. zamiaru przebywania, należy mieć na uwadze, że składnik mentalny animus nie może być oceniony tylko i wyłącznie na podstawie wewnętrznego przekonania, pozytywnego stosunku emocjonalnego do danej miejscowości czy wreszcie deklaracji słownej lub zapewnień. Aby był on wiarygodny, musi jeszcze wyrażać się w postaci konkretnych sprawdzalnych zachowań - które będą jego potwierdzeniem. Nie wystarczy w tej mierze jedynie złożenie oświadczenia czy zapewnień przez zainteresowaną osobę o danym zamiarze. Muszą temu oświadczeniu jeszcze towarzyszyć codzienne czynności faktyczne i prawne, które będą jego wyrazem.

Jak wskazał Wojewódzki Sąd Administracyjny w Gliwicach w wyroku z 27 lutego 2017 r. ${ }^{9}$ o „miejscu zamieszkania” rozstrzyga zawsze całokształt okoliczności faktycznych składających się na ziszczenie się stanu faktycznego przebywania z zamiarem takiego przebywania. Sam zamiar stałego pobytu w danej miejscowości nie stanowi jeszcze o zamieszkaniu, musi być on nierozerwalnie powiązany z przebywaniem $\mathrm{w}$ danej miejscowości, i to z takim przebywaniem, które ma cechy założenia tam ośrodka swoich interesów życiowych. O stałości pobytu danej osoby w konkretnej miejscowości decyduje przede wszystkim takie przebywanie tej osoby, które spełnia wskazaną wyżej cechę, czyli założenia i prowadzenia tam ośrodka swoich życiowych interesów, ich kumulacji. O miejscu zamieszkania nie decydują jedynie kryteria administracyjne, jak zameldowanie, ale fakt przebywania tam określonej osoby oraz uczynienie przez nią z tego miejsca centrum życiowego, centrum osobistych interesów.

Tak więc, jak słusznie wskazał Wojewódzki Sąd Administracyjny w Łodzi w wyroku z 11 stycznia 2018 r. $^{10}$, o miejscu zamieszkania dla określenia praw wyborczych decydują zatem dwie przesłanki faktyczne, które muszą wystąpić łącznie: przebywanie w znaczeniu fizycznym w określonej miejscowości pod ozna-

8 Sygn. akt II SA/Lu 254/16, LEX nr 2258575.

9 Sygn. akt IV SA/Gl 1181/16, LEX nr 2255173.

10 Sygn. akt III SA/Ld 604/17, LEX nr 2444322. 
czonym adresem oraz zamiar stałego pobytu w tym miejscu. Na stałość pobytu w danej miejscowości wskazuje skupienie w niej życiowej aktywności, związanej z pracą czy rodziną, jednakże zamiar stałego pobytu ma charakter subiektywny, w związku z czym jego ustalenie może napotykać trudności. Z tego powodu dla oceny miejsca stałego pobytu nie należy kierować się wyłącznie oświadczeniami osoby zainteresowanej. Konieczne jest też uwzględnienie okoliczności zewnętrznych mogących świadczyć o tym, że dana osoba rzeczywiście zamierza stale przebywać w tej miejscowości. Nie sposób ustalić pewnego, obiektywnego (np. czasowego) miernika stałego pobytu, co oznacza, że każdy przypadek wymaga indywidualnej oceny. Ta ocena winna być dokonywana na podstawie okoliczności ustalonych w sposób niebudzący wątpliwości i znajdujących potwierdzenie w zebranych dowodach, co do których radny miał możliwość wypowiedzenia się jeszcze przed podjęciem uchwały. Przynależność do wspólnoty samorządowej powstaje ex lege z chwilą zamieszkania na terenie określonej jednostki samorządu terytorialnego, bez względu na dopełnienie obowiązku meldunkowego. Uprawnienia do głosowania $\mathrm{w}$ wyborach samorządowych nie należy bowiem wiązać z dokonaniem czynności materialno-technicznej, jaką jest zameldowanie. Instytucja zameldowania ma charakter wyłącznie ewidencyjno-porządkowy.

\section{Wygaśnięcie mandatu radnego}

Zgodnie z art. $383 \$ 1$ pkt 2 Kodeksu wyborczego wygaśnięcie mandatu radnego następuje w przypadku utraty prawa wybieralności lub nieposiadania go w dniu wyborów.

Zgodnie z treścią art. $383 \$ 2$ wygaśnięcie mandatu radnego z przyczyn, o których mowa w $\$ 1$ pkt 2 (z wyjątkiem powodów wskazanych w art. $10 \$ 2^{11}$ i art. $11 \$ 2^{12}$, oraz pkt $3^{13}, 5^{14}$ i $7^{15}$ ), stwierdza rada, w drodze uchwały, w terminie miesiąca od dnia wystąpienia przyczyny wygaśnięcia mandatu.

11 Art. $10 \$ 2$. Nie ma prawa wybierania osoba:

1) pozbawiona praw publicznych prawomocnym orzeczeniem sadu;

2) pozbawiona praw wyborczych prawomocnym orzeczeniem Trybunału Stanu;

3) ubezwłasnowolniona prawomocnym orzeczeniem sądu.

12 Art. $11 \$ 2$. Nie ma prawa wybieralności w wyborach osoba:

1) skazana prawomocnym wyrokiem na kare pozbawienia wolności za przestępstwo umyślne ścigane z oskarżenia publicznego lub umyślne przestępstwo skarbowe;

2) wobec której wydano prawomocne orzeczenie sądu stwierdzajace utrate prawa wybieralności, o którym mowa w art. 21a ust. 2a ustawy z dnia 18 października 2006 r. o ujawnianiu informacji o dokumentach organów bezpieczeństwa państwa $z$ lat 19441990 oraz treści tych dokumentów, Dz.U. 2017, poz. 2186 oraz 2018, poz. 538.

13 Odmowa złożenia ślubowania.

14 Naruszenie ustawowego zakazu łączenia mandatu radnego z wykonywaniem określonych w odrębnych przepisach funkcji lub działalności.

15 Niezłożenie w terminach określonych w odrębnych przepisach oświadczenia o swoim stanie majątkowym. 
Przepisu Kodeksu wyborczego nie przewidują w tej sytuacji unieważnienia mandatu ${ }^{16}$.

Przed podjęciem uchwały o wygaśnięciu mandatu należy umożliwić radnemu złożenie wyjaśnień.

Uchwałę rady o wygaśnięciu mandatu radnego doręcza się niezwłocznie zainteresowanemu i przesyła wojewodzie oraz komisarzowi wyborczemu. Postanowienie komisarza wyborczego o wygaśnięciu mandatu radnego doręcza się niezwłocznie zainteresowanemu i przesyła wojewodzie oraz przewodniczącemu rady.

Inicjatorem podjęcia sprawy, która prowadzi do wszczęcia postępowania wyjaśniającego, może być każdy. Może to być nawet anonimowe pismo. Na przykład do wyroku Wojewódzkiego Sądu Administracyjnego w Olsztynie z 5 lipca 2016 r. ${ }^{17}$ doprowadziło: pismo mieszkańca Giżycka, w którym wskazano, że radny wspólnie z żona i dziećmi na stałe mieszka $w$ W., gdzie prowadza wspólnie gospodarstwo domowe i gdzie znajduje się jego centrum aktywności życiowej oraz gdzie ma zarejestrowaną swoja działalność gospodarczą.

Obowiązkiem rady - po powzięciu informacji wskazujących na możliwość niespełnienia przesłanki stałego zamieszkiwania w dniu wyborów bądź też po wyborze - jest przeprowadzenie postępowania wyjaśniającego. Należy wezwać radnego do złożenia wyjaśnień, udokumentowania faktu stałego rzeczywistego zamieszkiwania. Możliwe jest np. przeprowadzenia wywiadu wśród sąsiadów czy mieszkańców.

Na przykład w uzasadnieniu wyroku z 11 października 2016 r. Wojewódzki Sąd Administracyjny w Łodzi przytoczył następujące czynności rady, które zmierzały do ustalenia miejsca zamieszkania radnego: rada powołała się na notatke pracownika Urzędu Miejskiego w Z., z dnia 9 marca 2016 r., z której wynika, że skarżący jako właściciel nieruchomości odmówił dostarczenia pojemników na gromadzenie odpadów, uzasadniających to faktem, że nie zamieszkuje na terenie nieruchomości. Rada wskazała także na informacje elektroniczna od A sp. z o.o. $z$ dnia 9 marca 2016 r., w której wskazano, że nieruchomość nie została wyposażona w pojemniki z uwagi na nieprzebywanie na terenie nieruchomości kogokolwiek. Ponadto, zdaniem Rady, kolejna okolicznościa świadcząca o braku prawa wybieralności jest pismo B Spótki sp. z o.o. z dnia 29 marca 2016 r., w którym wskazano, że od 16 sierpnia 2013 r. nie ma możliwości odczytania wskazań wodomierza poprzez brak kogokolwiek na terenie nieruchomości. Ponadto powołano się na okoliczność co najmniej trzykrotnego braku odbioru korespondencji pod wskazanym adresem. W dniu 2 marca 2016 r. przeprowadzono też oględziny nieruchomości,

16 Tak M. Szczypińska-Grabarczyk w Opinii prawnej z dnia 3 kwietnia 2015 r., w sprawie miejsca zamieszkania radnego, BAS-WAL 553/15, niepubl.

17 Sygn. akt II SA/Ol 835/16, LEX nr 2083923. 
z udziałem Burmistrza, Zastępcy Burmistrza i pracownika urzędu uznając, że jej stan techniczny nie pozwala na zamieszkiwanie ${ }^{18}$.

Zanim doszło do wydania 27 lutego 2017 r. wyroku WSA w Gliwicach ${ }^{19}$, Rada Miasta K. zleciła Komisji Rewizyjnej kontrolę w zakresie legalności sprawowania mandatu przez radnego i wystosowała prośbę do: a) Burmistrza Gminy i Miasta C. z zapytaniem, czy M. S. zamieszkuje wraz z rodzina na terenie Gminy C. oraz czy i gdzie na terenie Gminy C. dzieci jego realizuja obowiązek szkolny, b) Komendanta Komisariatu Policji w C. z zapytaniem, czy M. S. zamieszkuje wraz $z$ rodzina na terenie Gminy C. przy ul. [...] i pod jakim numerem, c) Komendanta Komisariatu Policji w K. z zapytaniem, czy M. S. wraz z rodzina zamieszkuje w K. przy ul. [...], d) Prezydenta Miasta K. z zapytaniem, o miejsce zameldowania, o obowiązk podatkowym, o uiszczeniu opłat za odpady, o wykonaniu obowiazku szkolnego przez dzieci radnego M. S., e) Dyrektora Zespołu Szkół nr [...] w C. zzapytaniem, czy i od kiedy A. S. córka M. S. realizuje swój obowiązek szkolny w Zespole Szkół nr [...] w C., f) Dyrektora Szkoły Podstawowej im. [...] w P. z zapytaniem, czy i od kiedy H. S. córka M. S. realizuje swój obowiązek szkolny w Szkole Podstawowej im. [...] $w$ P.

Następnie - w terminie miesiąca od dnia wystąpienia przyczyny wygaśnięcia mandatu - jeśli potwierdzą się informacje o niespełnieniu przesłanki stałego zamieszkiwania - rada podejmuje uchwałę o wygaśnięciu mandatu, którą doręcza się radnemu, przesyła wojewodzie i przewodniczącemu rady. Zdaniem WSA we Wrocławiu $^{20}$, chociaż żaden przepis prawa nie obliguje rady gminy do sporządzenia uzasadnienia uchwały stwierdzającej brak podstaw do wygaśnięcia mandatu radnego czy uchwały o stwierdzeniu wygaśnięcia mandatu zgodnie z wymogami art. $107 \$ 1$ i $\$ 3$ k.p.a., to jednak ze względu na charakter tej uchwały, jak również jedną z zasad, mającej charakter uniwersalnej, związanej z wymogiem pogłębiania zaufania do państwa, zasadne jest zawrzeć w niej wyżej opisane elementy, które umożliwią dokonanie kontroli jej legalności.

$\mathrm{Z}$ treści art. $383 \$ 2$ Kodeksu wyborczego wynika wprost, że w przypadku zaistnienia okoliczności wymienionych w $\$ 1$ pkt 2 (utraty prawa wybieralności) rada - w drodze uchwały - stwierdza wygaśnięcie mandatu. Zatem podstawowe znaczenie ma wystąpienie enumeratywnie w ustawie wymienionych okoliczności faktycznych, które skutkują wygaśnięciem mandatu. Uchwała rady stwierdza jedynie wystąpienie tych okoliczności i zobowiązana jest podjąć stosowną uchwałę. Uchwała o wygaśnięciu mandatu radnego nie jest aktem prawa miejscowego. Powyższe oznacza, że nie podlega ona szczególnemu reżimowi zarówno co do spo-

18 Https://pkw.gov.pl/pliki/1478517579_Wyrok\%20WSA\%20w\%20\%C5\%81odzi\%20 z\%202016-10-11_Uzasadnienie.pdf [dostęp 30 stycznia 2019 r.].

19 Sygn. akt IV SA/Gl 1181/16, http://orzeczenia.nsa.gov.pl/doc/A09F019D6E [dostęp 30 stycznia 2019 r.].

20 Wyrok z 3 stycznia 2013 r., sygn. akt III SA/Wr 502/12, LEX nr 1330097. 
sobu publikacji (wojewódzki dziennik urzędowy), jak i terminu wejścia w życie, przewidzianych w ustawie z 20 lipca 2000 r. o ogłaszaniu aktów normatywnych i niektórych innych aktów prawnych (Dz.U. 2017, poz. 1523, ze zm.) ${ }^{21}$.

Zgodnie z art. 384 \$1-3 Kodeksu wyborczego na uchwałę rady o wygaśnięciu mandatu radnego zainteresowanemu przysługuje skarga do sądu administracyjnego w terminie 7 dni od dnia doręczenia uchwały. Skargę wnosi się za pośrednictwem organu, który stwierdził wygaśnięcie mandatu, w terminie 14 dni. Sąd administracyjny rozpatruje tę skargę $\mathrm{w}$ terminie $14 \mathrm{dni}$ od dnia jej wniesienia. Wygaśnięcie mandatu radnego następuje z dniem uprawomocnienia się wyroku sądu administracyjnego oddalającego skargę.

Zainteresowanym w rozumieniu art. $384 \$ 1$ Kodeksu wyborczego jest radny, którego mandat wygasł, bowiem tylko jego praw i obowiązków dotyczy bezpośrednio uchwała (postanowienie) stwierdzająca wygaśnięcie mandatu.

$\mathrm{W}$ związku z wygaśnięciem mandatu radnego dalsze postępowanie zależy od wielkości gminy. W przypadku wygaśnięcia mandatu radnego rady gminy w gminie liczącej do 20000 mieszkańców wojewoda zarządza wybory uzupełniające, które przeprowadza się w ciągu 3 miesięcy od daty stwierdzenia wygaśnięcia mandatu, z tym że wyborów uzupełniających nie przeprowadza się, jeżeli ich data przypadałaby w okresie 6 miesięcy przed zakończeniem kadencji rad (art. 385 i art. 386 Kodeksu wyborczego).

W przypadku stwierdzenia wygaśnięcia mandatu radnego wybranego w okręgu wyborczym dla wyboru rady gminy w gminie liczącej powyżej 20000 mieszkańców oraz mandatu radnego powiatu lub województwa komisarz wyborczy postanawia o wstąpieniu na jego miejsce kandydata z tej samej listy, który w wyborach uzyskał kolejno największą liczbę głosów, a nie utracił prawa wybieralności. Przy równej liczbie głosów - mandaty przypadające danej liście kandydatów uzyskują kandydaci w kolejności otrzymanej liczby głosów. Jeżeli dwóch lub więcej kandydatów otrzymało równą liczbę głosów uprawniającą do uzyskania mandatu $z$ danej listy, o pierwszeństwie rozstrzyga większa liczba obwodów głosowania, w których jeden z kandydatów uzyskał więcej głosów, a jeżeli liczba tych obwodów byłaby równa, o pierwszeństwie rozstrzyga losowanie przeprowadzone przez przewodniczącego okręgowej komisji wyborczej w obecności członków komisji oraz pełnomocników wyborczych; nieobecność pełnomocnika wyborczego nie wstrzymuje losowania. Przebieg losowania opisuje się w protokole wyników wyborów. Tryb przeprowadzania losowania określa Państwowa Komisja Wyborcza.

Kandydat może zrzec się pierwszeństwa do obsadzenia mandatu na rzecz kandydata $\mathrm{z}$ tej samej listy, który uzyskał kolejno największą liczbę głosów. Oświadczenie to powinno być zgłoszone komisarzowi wyborczemu na piśmie

21 Wyrok Wojewódzkiego Sądu Administracyjnego z siedzibą w Olsztynie z 15 listopada 2011 r., sygn. akt II SA/Ol 751/11, Legalis nr 416417. 
w ciągu 3 dni od daty doręczenia zawiadomienia o przysługującym mu mandacie (art. 387 Kodeksu wyborczego).

\section{Podsumowanie}

Bierne i czynne prawo wyborcze w wyborach do organów stanowiących jednostek samorządu terytorialnego jest powiązane $\mathrm{z}$ faktem stałego zamieszkiwania na terenie danej jednostki samorządu terytorialnego, a nie $\mathrm{z}$ faktem zameldowania. Instytucja zameldowania ma charakter wyłącznie ewidencyjno-porządkowy i nie można utożsamiać miejsca zamieszkania z miejscem zameldowania na pobyt stały, z czynnością zameldowania nie wiąże się bowiem nabycie jakichkolwiek praw i obowiązków. Decydujące dla ustalenia stałego miejsca zamieszkania kandydata w wyborach samorządowych jest przebywanie fizyczne w określonej miejscowości pod oznaczonym adresem oraz zamiar stałego pobytu w tym miejscu.

Wygaśnięcie mandatu radnego następuje w przypadku utraty prawa wybieralności lub nieposiadania go w dniu wyborów. Niespełnienie przez radnego przesłanki stałego zamieszkiwania w dniu wyborów bądź też odpadnięcie tej przesłanki po wyborze na radnego oznacza nieposiadanie prawa wybieralności w dniu wyborów lub utratę tego prawa, co skutkuje wygaśnięciem mandatu. Wygaśnięcie mandatu stwierdza rada, w drodze uchwały, w terminie miesiąca od dnia wystąpienia przyczyny wygaśnięcia mandatu.

Przed podjęciem uchwały o wygaśnięciu mandatu należy ustalić, czy spełniona jest przesłanka „stałego zamieszkiwania” na obszarze gminy, i umożliwić radnemu złożenie wyjaśnień. Rada może dokonywać ustaleń w tym zakresie, posiłkując się np. wywiadem środowiskowym czy informacjami uzyskanymi od właściwych instytucji.

Od uchwały rady o wygaśnięciu mandatu radnego zainteresowanemu przysługuje skarga do sądu administracyjnego w terminie 7 dni od dnia doręczenia uchwały albo postanowienia.

W zależności od wielkości gminy w gminie przeprowadza się następnie wybory uzupełniające albo komisarz wyborczy postanawia o wstąpieniu na zwolnione miejsce kandydata $\mathrm{z}$ tej samej listy, który w wyborach uzyskał kolejno największą liczbę głosów, a nie utracił prawa wybieralności.

\section{Bibliografia}

Kisielewicz A., Zbieranek J., Komentarz do art. 5 [w:] K. Czaplicki, B. Dauter, S. Jaworski i in., Kodeks wyborczy. Komentarz, Wolters Kluwer, Warszawa 2018. 